\title{
Violência e ensino de Filosofia no Brasil'
}

\section{Violence and teaching of Philosophy in Brazil}

\author{
Evanildo Costeski \\ Orcid: https://orcid.org/0000-0001-8713-915X - E-mail:evanildoc@uol.com.br
}

\begin{abstract}
RESUMO
Este artigo contem dois momentos: em um primeiro, são apresentados quatro tipos de violência: a violência por "ignorância", a violência social, a violência estatal e a violência filosófica, e a relação com o Ensino de Filosofia no Brasil; em um segundo, é exposto o encontro dos europeus com os índios brasileiros, por meio dos escritos de Manuel da Nóbrega. Veremos como o medo foi utilizado pelos jesuítas para convencer os indígenas a se converterem e, por último, exporemos brevemente como o conceito de escravidão voluntária influenciou a constituição do direito subjetivo moderno.
\end{abstract}

Palavras-chave: Ensino de Filosofia, Violência, Missões Jesuíticas, Medo.

\begin{abstract}
This article contains two moments: at first, four types of violence are presented: violence for "ignorance", social violence, state violence and philosophical violence, and the relationship with philosophy teaching in Brazil; in a second, the encounter between Europeans and Brazilian Indians is exposed, through the writings of Manuel da Nóbrega. We will see how fear was used by the Jesuits to convince Brazilian Indians to convert and, finally, we will briefly expose how the concept of voluntary slavery influenced the constitution of modern subjective law.
\end{abstract}

Keywords: Teaching Philosophy, Violence, Jesuit Missions, Fear.

\footnotetext{
1 Este artigo se insere no âmbito de pesquisa do NEB-Núcleo de Estudos Brasileiros, do Curso de Filosofia do Instituto de Cultura e Arte da UFC. Agradeço ao Daniel Benevides Soares pelos comentários e sugestões que muito contribuíram para a redação final.
} 


\section{Introdução}

A violência permeia toda a realidade, seja natural ou artificial, produzida ou não pela ação humana ${ }^{2}$. No presente texto, sem desprezar a violência natural, será dada uma atenção especial à violência engendrada pela ação humana, inerente à história brasileira.

Assim como a de outras nações, a história do Brasil é uma história sangrenta. Entretanto, desde o início buscou-se "adocicar" essa violência produzida pelos conquistadores-colonizadores cristãos, em nome do Império Português e da Igreja Católica. Em vez de fundar uma nação independente, o objetivo dos primeiros conquistadores cristãos era evangelizar e colonizar, pela cruz e pela espada, os povos endógenos e exógenos, estes trazidos especialmente da África, para a extração e a produção de bens necessários ao Império português e aos demais países europeus.

Essa história é conhecida: de cerca 05 milhões de indígenas na época da ocupação europeia, resistem hoje cerca de 460 mil, especialmente na região norte do país; em relação à escravidão, estima-se que 03 a 04 milhões de africanos foram trazidos para o Brasil e aqui padeceram inúmeras formas de violência. Evidentemente, houve resistências e revoluções, todas combatidas com mais violência, justificada com argumentos econômicos, jurídicos, filosóficos e teológicos.

A violência é a regra, não a exceção, na história brasileira. Com o fim da escravidão e do Império, ela não deixou evidentemente de existir. O Estado Republicano, que deveria resguardar os brasileiros mais necessitados, não hesitou, para proteger interesses de fazendeiros e de políticos gananciosos, de produzir, por exemplo, os massacres de Canudos e Caldeirão e de sustentar inúmeras formas de exploração do povo pobre brasileiro, até os dias de hoje.

No presente momento da República Brasileira, assiste-se a uma agressão sem precedentes, porque imprimida em nome do Estado brasileiro, contra as populações indígenas e grupos quilombolas remanescentes, contra a população mais necessitada, contra as florestas e a natureza em geral.

Diante desse quadro deprimente e revoltante, pode-se perguntar: como fica a educação e a filosofia? Segundo o nosso ponto de vista, o Ensino de Filosofia universitário e secundário brasileiro não pode ficar alheio a esse processo. Uma resposta precisa ser dada ao problema da violência latente em nossa história. Como indicou Eric Weil, a violência é o outro sem o qual a filosofia não se compreende. É preciso olhar de frente para a violência revelar o seu segredo oculto. De fato:

Não basta fazer como se a violência não existisse, não falar a respeito, recalcar o medo: ela se anuncia, mesmo ao filósofo, no medo do medo; também no homem que quer ser razoável, que se pretende razão, a paixão ainda é a mola propulsora de seu movimento de fuga diante do movimento e do devir, e a violência, o que não depende dele, mas lhe acontece, é o que lhe dá coragem de seu medo. É preciso que ele se volte para a violência e a olhe de frente (WEIL, 2012, p. 36).

Dividiremos a nossa reflexão em dois momentos. Em um primeiro, apresentaremos uma reflexão geral sobre a presença da violência na história brasileira e, em um segundo, faremos um estudo de caso sobre a violência praticada pelos colonos e missionários jesuítas no início da colonização brasileira, a partir da obra do padre Manuel da Nóbrega. Avisamos ao leitor que esse estudo é ainda inicial, um work in progress, que almejamos completar no futuro.

\footnotetext{
2 Sobre a relação Filosofia e Violência, ver a "Introdução" à Lógica da Filosofia de Eric Weil (2012, p. 11-128).
} 


\section{Para uma tipologia da violência na história brasileira}

Para facilitar a nossa compreensão, delinearemos abaixo uma tipologia da violência subjacente na história brasileira. Esses tipos não são evidentemente estanques nem definitivos. Podem inclusive sofrer alterações durante os períodos históricos. Propõem-se, inicialmente, quatro tipos: a violência justificada de forma preconceituosa devido a uma suposta "ignorância" da população indígena e afro-brasileira, a violência social, a violência estatal e a violência filosófica, isto é, a violência com conhecimento de causa.

\section{a) A violência praticada por suposta "ignorância"}

A violência por "ignorância" foi utilizada de forma preconceituosa para justificar e validar o abuso praticado pelos conquistadores europeus contra os indígenas e os negros africanos. Parte-se do princípio de que apenas o homem branco cristão detém a verdade; deve-se simplesmente aceitar a supremacia do conquistador. Toda ação violenta visando à salvação do "ignorante" é plenamente justificada e vista como natural. Ressalta-se que essa violência, predominante no período colonial e imperial, continua a atuar ainda hoje, nas várias formas de racismo, machismo, homofobia, supremacia branca, superioridade cristã etc. Para quem acha que retém a verdade, o outro é sempre ignorante e, portanto, pode ser descartado, subjugado e até eliminado.

\section{b) A violência social}

A violência social seria aquela produzida pela sociedade contra a natureza e a comunidade humana em geral. Como um exemplo óbvio, poderíamos pensar naquela praticada pelas classes sociais mais poderosas contra as menos favorecidas, potencializada pelo capitalismo selvagem. Poder-se-ia também inserir nessa violência a destruição dos rios e das florestas causada pelas grandes indústrias, agronegócio e mineradoras ilegais, por exemplo. A falta de educação, de saúde e de emprego poderia igualmente ser incluída nesse tipo de violência, além da carência de cultura e de opções de divertimento para os jovens, que podem levar ao tédio, às drogas e aos suicídios. Tudo isso é claramente um desafio para um Ensino de Filosofia contextualizado, a partir da situação social, cultural e psicológica dos jovens.

\section{c) A violência estatal}

A violência estatal é evidentemente aquela praticada pelo Estado, o qual deveria, em princípio, proteger a todos os cidadãos, principalmente os mais necessitados. É certo que o Brasil não teve uma violência estatal totalitária, como aquela produzida pelo Fascismo, pelo Nazismo ou pelo Stalinismo, porém, nem por isso deixou de ter outros "ismos", como o totalitarismo da "Era Vargas" e o da ditatura militar. Na verdade, mesmo sem um governo totalitário, o Estado brasileiro nunca deixou de cometer arbitrariedades. Sabe-se que o Estado exerce o monopólio da violência e que, por isso, deve garantir a segurança de todos os cidadãos e impor a lei, por meio de forças militares e civis. Todavia, a repressão violenta deveria ser o último recurso do Estado. Além da segurança, o Estado deveria garantir educação, saúde e justiça social para todos. Infelizmente, o que vigora no Brasil é a violência praticada pelo Estado e, de forma inversamente proporcional, a violência procedente da ausência do Estado, a qual, paradoxalmente, pode ser considerada igualmente como um tipo de violência estatal. Sem o Estado, tudo é permitido, principalmente contra os mais fracos.

\section{d) A violência filosófica}

O último tipo de violência pensado aqui é o que estamos denominando de violência filosófica ou, simplesmente, com conhecimento de causa. Não se trata, evidentemente, de uma 
violência produzida pela filosofia, mas sim oriunda da ausência de filosofia ou mesmo contra a filosofia; daí ser chamada de filosófica. Ou seja, conscientemente ou com conhecimento de causa, nega-se a filosofia porque simplesmente considera-se que ela não tem mais importância para a educação e para a sociedade. Neste tipo de violência, o que vigora é a racionalidade técnica. Para quê filosofia, se ela não serve para nada? ${ }^{3}$. É isso que afirmam os burocratas e uma parte da sociedade, mais preocupada com seus interesses imediatos. $O$ problema é que, sem a filosofia, a própria vida perde sentido. Esta é a verdadeira violência e o principal desafio para o Ensino de Filosofia. A negação da filosofia leva à negação do Sentido, ao desespero, ao predomínio do tédio violento na vida quotidiana ${ }^{4}$. Sem a discussão filosófica nas Escolas, os jovens dificilmente farão as perguntas primordiais da vida humana: Quem sou seu? Para aonde vou? Por que existe o ser e não o nada? Para ilustrar ainda mais essa situação, podemos pensar também nas três perguntas kantianas: O que posso saber? O que eu deveria fazer? O que posso esperar? Sem filosofia, nada do que realmente interessa poderá ser criticado, refletido e conhecido. $\mathrm{Na}$ Grécia antiga, a filosofia surgiu na Pólis, na ágora, exercitando o diálogo e as disputas públicas, buscando eliminar ou mitigar a violência. A experiência socrática é emblemática e permanece atual. A atitude socrática foi e será sempre uma das mais nobres posições filosóficas contra a violência. Acima de tudo, a filosofia é diálogo e respeito pelas posições democráticas, visando formar o cidadão crítico, com responsabilidades éticas e sociais, contra todo tipo de violência.

A partir do que foi exposto, podemos perguntar: como se deve conceber o Ensino de Filosofia no Brasil, diante desse painel extremamente brutal apresentado acima? Podemos identificar na história filosófica brasileira momentos em que a filosofia se opôs e se compreendeu a partir da violência. Na Colônia, pode-se considerar, por exemplo, o pensamento do padre Antônio Vieira, que corajosamente se opôs à escravidão dos índios, apesar de justificar a dos negros africanos ${ }^{5}$. Ganhe-se de um lado, perde-se de outro; isso, infelizmente, é recorrente na história brasileira. Já na primeira metade do século XIX, nota-se como o ecletismo espiritualista adotado por Gonçalves Magalhães se tornou a filosofia oficial da primeira fase do Império, época em que o Brasil correu um sério risco de se desintegrar territorialmente. $O$ ecletismo, justamente por valorizar todas as posições ideológicas, acabou exercendo um papel fundamental, ainda que questionável, para a pacificação do Império ${ }^{6}$. No final do Império, observa-se como o positivismo se impôs ao pensamento brasileiro, colaborando com o fim da escravidão e com a ascensão do espírito republicano ${ }^{7}$. O predomínio exagerado do positivismo científico no pensamento brasileiro no final do século XIX levou Tobias Barreto a defender, no final da sua vida, o que passaria a ser chamado posteriormente de Culturalismo, ou seja, a superioridade do espírito humano diante de todo tipo de determinismo. Diz Tobias Barreto:

Assim, por exemplo, se alguém hoje ainda ousa repetir com Aristóteles que há homens nascidos para escravos, não vejo motivo de estranheza. Sim - é natural a existência da escravidão; há até espécies de formigas, como a polyerga rubescens, que são escravocratas; porém é cultural que a escravidão não exista. (...) Do mesmo modo, é um resultado natural da luta pela vida que haja grandes e pequenos, fortes e fracos, ricos e pobres, em atitude hostil uns aos outros; o trabalho cultural consiste, porém, na harmonização dessas divergências, medindo a todos por uma só bitola. (BARRETO, 1977, 330).

\footnotetext{
3 Sobre a recusa da filosofia, ver Eric Weil (2012, p. 23-36).

4 Sobre a relação da violência com o tédio e a falta de sentido no mundo contemporâneo, ver Eric Weil (2000, p. 55-70).

5 Sobre isso, ver, por exemplo, Paulo Margutti (2013, p. 244-267).

6 Sobre o pensamento de Gonçalves Magalhães, ver Roque Spencer Maciel de Barros (1973).

7 Sobre a importância do positivismo para o pensamento brasileiro, ver Cruz Costa (1967, p. 123-276).
} 
Essa posição será retomada e aprofundada por Farias Brito no início do século XX. Não se trata de retornar à metafísica salvacionista que vigorou no Brasil até meados do XIX, mas sim de defender a superioridade do espírito humano, que põe o problema da vida e do sentido, contra todo tipo de violência determinista inerente ao pensamento técnico-positivista. Farias Brito antecipa, de certa forma, em suas instigantes reflexões, questões que serão desenvolvidas depois pelo existencialismo europeu após a segunda guerra, e que permanecem atuais para o pensamento brasileiro contemporâneo ${ }^{8}$.

Como se sabe, o Brasil teve que esperar até a metade do século XX para instaurar suas primeiras Universidades e, com elas, os cursos de filosofia profissionais. O curso de filosofia da USP, criado na década de 1930 e patrocinado pelo governo francês, tornou-se rapidamente o modelo a ser seguido. O método adotado foi o da leitura estrutural imanente de textos filosóficos clássicos, em detrimento de temas filosóficos livres, evitando, assim, o diletantismo filosófico reinante até então ${ }^{9}$. Embora exagerado, esse ponto de vista metodológico continua a ser importante para os cursos de filosofia e para a própria filosofia no Ensino Médio, que não podem simplesmente prescindir do estudo do pensamento clássico. O contraponto ao modelo uspiano foi proporcionado à época pelo ISEB, na década de 1950 e início de 1960. Patrocinado pelo governo Kubitschek, o ISEB-Instituto Superior de Estudos Brasileiros, buscou vincular a pesquisa filosófica com o desenvolvimento nacional. Com efeito, o estudo da filosofia clássica é fundamental, mas não pode prescindir da consciência filosófica nacional ${ }^{10}$. Em nossa opinião, em que pese a carga ideológica do "desenvolvimentismo" do governo de Kubitschek (50 anos em 05) subjacente a esse princípio filosófico, devemos resgatá-lo no Ensino de Filosofia atual. De fato, o Ensino de Filosofia no Brasil não pode prescindir do pensamento brasileiro, do contrário, a filosofia se tornará cada vez mais esotérica, voltada apenas para si mesma, sem captar a realidade brasileira. Sem debates e sem reflexões sobre o Brasil, perde-se o próprio sentido democrático, com a violência se fortalecendo gradativamente na sociedade brasileira.

A liberdade é um aprendizado e o espírito crítico deve ser constantemente cultivado para a democracia ser exercitada. Democracia é um valor em si, mas sem a filosofia, ou seja, sem o cultivo do espírito critico, pode se tornar facilmente uma ditadura da maioria contra os próprios valores democráticos ${ }^{11}$. Sem pensamento crítico, o nacionalismo tosco impera e a própria democracia perde sentido. Nesse aspecto, as consequências negativas causadas pelo totalitarismo militar, levado a cabo com a supressão da filosofia do Ensino médio, foram irreparáveis para a cultura brasileira.

O retorno da filosofia na primeira década do século XXI não conseguiu ainda reverter essa situação, que tende a se agravar com a recente retirada da obrigatoriedade filosofia do Novo Ensino Médio. A ausência de pensamento crítico nas escolas acabou criando uma atmosfera favorável a todo tipo de aventura pseudo-filosófica, potencializando possibilidades de violência latentes, principalmente contra os movimentos sociais defensores dos mais pobres e da ecologia.

\footnotetext{
8 Sobre a formação filosófica de Farias Brito, ver Laerte Ramos de Carvalho (1977).

9 Sobre a formação da filosofia uspiana, ver livro já clássico de Paulo Eduardo Arantes (1994).

10 Para uma visão crítica da filosofia isebiana e, em particular, de Álvaro Vieira Pinto, ver Bento Prado Junior (1985, p. 182-186).

11 Sobre os limites da democracia, considerados a partir da reflexão filosófica de Eric Weil, ver Judikael Castelo Branco (2019, p. 249-259).
} 


\title{
Um estudo de caso da violência no Brasil. Padre Manuel da Nóbrega e os encontros do novo mundo
}

Para ilustrar melhor pelo menos uma porção da violência praticada no Brasil e sua relação com o pensamento crítico filosófico, optaremos por dar destaque neste texto ao primeiro tipo de violência elencado acima, a saber, a violência justificada pela suposta "ignorância" dos índios brasileiros, cometida pelos europeus quando adentraram no Brasil. Para isso, nos deteremos no pensamento do padre jesuíta Manuel da Nóbrega, expresso principalmente no Diálogo sobre a Conversão do Gentio, considerado o primeiro texto em prosa escrito no Brasil, de 1556-1557, e na carta que ficou conhecida como Plano Civilizador, de 1558. Vale lembrar que nesse período não existiam ainda o ensino filosófico formal, pois os colégios foram criados pelos jesuítas apenas na década de 1560 . O que existia nessa época eram apenas as escolas de ler e aprender. A reflexão que vamos empreender agora, portanto, não é oriunda do Ensino de Filosofia propriamente dito, mas de uma reflexão filosófica em geral, produzida por meio do encontro do pensamento europeu com a cultura indígena.

Os textos citados acima são emblemáticos para a história do Brasil. Como se sabe, os primeiros jesuítas chegaram ao Brasil em 1549 com o primeiro governador-geral Tomé de Souza, depois do fracasso das capitanias hereditárias. Em princípio, os jesuítas acreditaram piamente na conversão dos indígenas, que pareciam aceitar com facilidade a pregação dos missionários. Eis o que escreve o padre Manuel da Nóbrega em sua primeira carta escrita no Brasil, em 10 de abril de 1549, dirigida ao padre Simão Rodrigues, provincial dos Jesuítas em Portugal:

\begin{abstract}
O irmão Vicente Rodrigues ensina a doutrina aos meninos cada dia e também tem escola de ler e escrever; parece-me bom modo este para trazer os índios desta terra, os quais têm grandes desejos de aprender e, perguntados se querem, mostram grandes desejos. (...). Desta maneira ir-lhes-ei ensinando as orações e doutrinando-os na fé até serem hábeis para o batismo. Todos estes que tratam conosco dizem que querem ser como nós, senão que não têm com que se cubram como nós, e este só inconveniente têm. Se ouvem tanger à missa, já acodem e quanto nos veem fazer, tudo fazem, assentam-se de joelhos, batem nos peitos, levantam as mãos ao Céu e já um dos principais deles aprende a ler e toma lição cada dia com grande cuidado e em dois dias soube o A, B, C todo, e o ensinamos a benzer, tomando tudo com grandes desejos. Diz que quer ser cristão e não comer carne humana, nem ter mais de uma mulher e outras coisas; somente que há de ir à guerra, e os que cativar, vendê-los e servir-se deles, porque estes desta terra sempre têm guerra com outros e assim andam todos em discórdia, comem-se uns a outros, digo os contrários. (NÓBREGA, 2017, p. 56-57).
\end{abstract}

Nesta primeira carta, além do entusiasmo com a acolhida dos índios, que vêm missa, "assentam-se de joelhos, batem nos peitos, levantam as mãos ao Céu", encontramos os elementos que irão tanto escandalizar a cultura europeia: a nudez, a poligamia e a antropofagia. A nudez acaba sendo relevada pelos jesuítas, simplesmente porque não se teria ainda uma quantidade de tecidos suficientes para cobrir de imediato todos os índios; mas a prática da poligamia e da antropofagia em particular constituirá um verdadeiro quebra-cabeça para os missionários. O canibalismo é realmente difícil de justificar ${ }^{12}$. Sabe-se que os índios canibalizados eram guerreiros que tinham sido capturados em guerra e tidos como assaz corajosos; portanto, em certo sentido, era uma honra ser vítima de tal prática. Pelo menos era isso que os guerreiros indígenas pensavam. Mas nada poderia abonar, aos olhos dos missionários, a violência de tal

\footnotetext{
${ }^{12}$ Sobre a prática do canibalismo entre os povos indígenas brasileiros, ver John Manuel Monteiro (1994, p. 27-28).
} 
ato. Definitivamente, a razão dos padres não tinha como aceitar o canibalismo, tido como abominável e intrinsecamente violento.

Mas será que é isso mesmo? O canibalismo é de fato injustificável? Michel de Montaigne, mais ou menos na mesma época, expressa uma posição totalmente contrária à dos padres jesuítas, no capítulo XXXI de seus Ensaios, intitulado justamente "Dos Canibais". Em princípio, Montaigne não vê"nada de bárbaro ou selvagem no que dizem daqueles povos; e, na verdade, cada qual considera bárbaro o que não se pratica em sua terra". (2016, p. 236-237). Em relação ao canibalismo em particular, diz Montaigne:

\begin{abstract}
Não me parece excessivo julgar bárbaros tais atos de crueldade, mas que o fato de condenar tais defeitos não nos leve à cegueira acerca dos nossos. Estimo que é mais bárbaro comer um homem vivo do que o comer depois de morto; e é pior esquartejar um homem entre suplícios e tormentos e o queimar aos poucos, ou entregá-lo a cães e porcos, a pretexto de devoção e fé, como não somente o lemos mas vimos ocorrer entre vizinhos nossos conterrâneos; e isso em verdade é bem mais grave do que assar e comer um homem previamente executado (2016, p. 240).
\end{abstract}

Temos, assim, praticamente no mesmo período, duas razões, duas posições filosóficas diferentes. É verdade que o canibalismo é execrável em si, porém, isso não dá direito de a razão ser hipócrita. É esse justamente o caso da razão europeia expressa pelos missionários jesuítas. Como vimos acima, Montaigne mostra muito bem que na Europa se fazia coisas muito piores. “Podemos portanto qualificar esses povos como bárbaros em dando apenas ouvidos à inteligência, mas nunca se os compararmos a nós mesmos, que os excedemos em toda sorte de barbaridades". (MONTAIGNE, 2016, p. 241). E certo que, no caso dos jesuítas, deve-se levar em consideração também o contexto político. Como se sabe, enquanto a Europa central se abria às novas experiências religiosas e científicas, ainda que de forma violenta, com as execráveis guerras religiosas, Portugal se fechava a essas renovações com a instalação da inquisição em 1536, no reinado de D. João III. Sem dúvida, uma posição como a de Montaigne seria certamente condenada pela Inquisição Portuguesa.

O fato é que o entusiasmo dos missionários pouco a pouco se esvai. Os índios ouvem os padres, participam das celebrações com entusiasmo, mas não mudam o seu modo de vida. Continuam a ter várias mulheres, a andar desnudos pelas matas, a guerrear e a comer os seus inimigos. E os padres nada podem fazer. Uma esperança surge com a nova pedagogia utilizada por José de Anchieta, que chegou ainda jovem ao Brasil em 1553, com o segundo governador-geral Dom Duarte da Costa. É sabido que os índios davam muito valor aos pajés e aos feiticeiros, chamados de caraíbas, que exerciam funções de cura e de comunicação com os espíritos $^{13}$. Anchieta, em vez de simplesmente pregar, exercia atividades de cura, sendo considerado um verdadeiro pajé e caraíba pelos índios, alcançando com isso resultados altamente positivos. Isso deu uma nova esperança ao padre Manuel da Nóbrega; porém, infelizmente, nem todos os jesuítas tinham a capacidade de Anchieta. E era praticamente impossível a ele atingir sozinho a todas as aldeias. Nesse ínterim, acontece a tragédia do Bispo Sardinha, que marcará profundamente o padre Manuel da Nóbrega e a história do Brasil. Pedro Fernandes Sardinha foi o primeiro bispo do Brasil, tomando posse em 1552. Em 1556, ao retornar para Portugal, naufraga na costa de Alagoas, e acaba sendo devorado, junto com toda a tribulação, pelos índios Caetés, segundo relatos.

Profundamente marcado por essa tragédia, Manuel da Nóbrega decide montar uma nova estratégia para a catequização e a ocupação do Brasil, aproveitando o apoio de Mem de

\footnotetext{
${ }^{13}$ Sobre os caraíbas, ver John Manuel Monteiro (1994, p. 24-25).
} 
Sá, terceiro Governador-Geral do Brasil. Para isso, escreverá o Diálogo sobre a Conversão do Gentio em 1556-1557 e o Plano Civilizador em 1558. Os interlocutores do Diálogo são Gonçalo Álvares e Mateus Nogueira, dois irmãos jesuítas ainda vivos, colegas de Manuel da Nóbrega. Gonçalo Álvares, conhecedor do Tupi, era tradutor, e Mateus Nogueira, ferreiro. Escreve Manuel da Nóbrega:

Porque me dá o tempo lugar para me alargar, quero falar com meus irmãos o que meu espírito sente. E tomarei por interlocutores ao meu irmão Gonçalo Álvares, a quem Deus deu graça e talento para ser trombeta de sua palavra na capitania do Espírito Santo, e com meu irmão Mateus Nogueira, ferreiro de Jesus Cristo, o qual posto que com palavra não prega, fá-lo com obras e marteladas. (2017, p. 201).

O texto é uma meditação de Manuel da Nóbrega, destinada aos irmãos jesuítas do mundo todo, sobre a sua preocupação atual em relação às missões brasileiras. No Diálogo, os dois personagens expressam inicialmente um grande desolação com o resultado das missões:

Gonçalo Álvares: Por demais é trabalhar com estes! São tão bestiais, que não lhes entra no coração coisa de Deus! Estão tão encarniçados em matar e comer, que nenhuma outra bem-aventurança sabem desejar! Pregar a estes é pregar em deserto a pedras.

Mateus Nogueira: Se tiveram rei, puderam-se converter ou se adoraram alguma coisa. Mas como não sabem que coisa é crer nem adorar, não podem entender a pregação do Evangelho, pois ela se funda em fazer crer e adorar a um só Deus e a esse só servir, e como este gentio não adora nada, nem crê nada, tudo o que lhe dizeis se fica nada. (NÓBREGA, 2017, p. 201-202).

Diferentemente de um paraíso idílico, onde os índios viveriam em um estágio de inocência, a visão de Manuel da Nóbrega, expressa pelos interlocutores, é de que os Tupis viviam em um estágio bestial, como selvagens, incapazes de se converterem. Entretanto, essa visão negativa choca-se claramente com o ideal jesuítico das missões, que imaginava multidões de pagãos aderindo à pregação dos missionários. A situação é realmente desoladora! O que fazer?

Ora, dizer que os índios eram selvagens, não significa afirmar que não eram humanos. Nesse aspecto, Manuel da Nóbrega não concorda com Aristóteles e os filósofos gregos em geral, que consideravam os que não eram gregos como bárbaros e subumanos. Os Tupis são selvagens, incivilizados, mas permanecem humanos, assim como os pagãos antigos e os atuais cristãos, por isso, devem ser visto como "próximos". Diz Nóbrega no Diálogo, por meio de seus personagens:

Gonçalo Álvares: Dizei-me, irmão Nogueira, esta gente são próximos?

Mateus Nogueira: Parece-me que sim.

Gonçalo Álvares: Por que razão?

Mateus Nogueira: Porque nunca me acho senão com eles, e com seus machados e foices.

Gonçalo Álvares: E por isso lhe chamais próximos?

Mateus Nogueira: Sim. Porque próximos, chegados quer dizer, e eles sempre se chegam a mim que lhes faça o que hão mister; e eu como a próximos Ihos faço, cuidando que cumpro o preceito de amar ao próximo como a mim mesmo, pois lhes faço o que eu queria que me fizessem, se eu tivesse a semelhante necessidade.

Gonçalo Álvares: Pois a pessoas muito avisadas ouvi eu dizer que estes não eram próximos, e porfiam-no muito, nem têm para si que estes são homens como nós.

Mateus Nogueira: Bem! Se eles não são homens, não serão próximos, porque só os homens, e todos, maus ou bons, são próximos. Todo homem é uma mesma natureza, e todo pode conhecer a Deus e salvar sua alma, e este ouvi eu dizer que era próximo. Prova-se no Evangelho do Samaritano, onde diz Cristo Nosso Senhor que aquele é próximo que usa de misericórdia. (2017, p. 207-208). 
Todos somos pecadores, por isso, temos a mesma sina, conforme observa o personagem Mateus Nogueira: “Depois que nosso pai Adão pecou, como diz o salmista, não conhecendo a honra que tinha, foi tornado semelhante à besta, de maneira que todos, assim portugueses, como castelhanos, como tamoios, como aimorés, ficamos semelhantes a bestas por natureza corrupta, e nisto todos somos iguais" (NÓBREGA, 2017, p. 215). Entretanto, há uma diferença essencial entre os pagãos tupis e os pagãos antigos, gregos e romanos, por exemplo. Enquanto estes eram civilizados e possuíam uma cultura e uma filosofia, pelo fato de fazerem uso da razão, os tupis são incivilizados, por isso, precisam de educação, de policia, isto é, de civilização.

Mas por que isso aconteceu? Por que Deus deu a razão a uns e a selvageria a outros? É o que pergunta um atônito Gonçalo Álvares: "Pois se assim é, que todos temos uma alma e uma bestialidade naturalmente, e sem graça todos somos uns: de que veio estes negros serem tão bestiais, e todas as outras gerações, como os romanos e os gregos e os judeus, serem tão discretos e avisados?" (NÓBREGA, 2017, p. 216). A explicação para isso é bíblica. Acreditava-se que os índios eram descendentes de Caim, filho de Noé, que descobriu as vergonhas de seu pai bêbado e caiu em maldição; por isso, como filhos de Caim, os índios permaneceram nus e tiveram outras misérias, como castigo. Os outros gentios, por serem descendentes de Sem e Jafé, eram da parte da razão, pois eram filhos de bênção e, por isso, tiveram alguma vantagem do ponto de vista da evolução da civilização.

Mas, independentemente disso, todos têm a mesma alma e entendimento. Na verdade, se a civilização ajuda de um lado, atrapalha de outro, da mesma forma que a simplicidade contribui de um lado e estorva de outro. Pelo pecado original, todos estão em um mesmo patamar; entretanto, surpreendentemente, do ponto de vista da fé e da salvação, parece que os selvagens Tupis têm mais proveito. De fato, diz Manuel da Nóbrega, por meio de Mateus Nogueira: "mais fácil é de converter um ignorante que um malicioso e soberbo". (2017, p. 219).

Quem é civilizado e educado, tem mais dificuldade em aceitar a fé. É verdade que, depois que se aceita, persevera-se com mais firmeza. Já o ignorante e o selvagem aceitam com mais facilidade a fé, mas depois são mais inconstantes e têm mais dificuldades em superar seus vícios naturais. O que fazer então? O plano de Manuel da Nóbrega será o de unir "conversão e civilização". Mas como se daria essa união?

\section{O medo e a sujeição violenta}

Como já foi dito, a pedagogia da palavra não deu os resultados esperados pelos missionários. A prática da cura, ao contrário, alcançou inicialmente excelentes resultados. Entretanto, acabou se tornando igualmente inviável, pelo fato de poucos jesuítas terem conhecimento da prática medicinal. Daí a necessidade de uma nova estratégia. Como assinala José Eisenberg, esta estratégia "aparece en passant no Diálogo de Nóbrega": (2000, p. 107). De fato:

Gonçalo Álvares: (...) Por amor de Deus, que me digais algumas das razões que os padres dão para estes gentios virem a ser cristãos; que alguns têm acertado que trabalhamos debalde ao menos até que este gentio não venha a ser muito sujeito e que com medo venha a tomar a fé.

Mateus Nogueira: E isso que aproveitaria, se fossem cristãos por força e gentios na vida e nos costumes e vontade?

Gonçalo Álvares: Aos pais, dizem os que têm esta opinião, que pouco; mas os filhos, netos e daí por diante o poderiam vir a ser, e parece que têm razão.

Mateus Nogueira: E a mim sempre me pareceu este muito bom e melhor caminho, se Deus 
assim fizesse, que outros. Não falemos em seus segredos e potência e sabedoria, que não há mister conselheiros, mas humanamente como homens assim falando, este parece o melhor e mais certo caminho. (NÓBREGA, 2017, p. 210-211).

Conforme relatado, o "medo" e a "sujeição violenta" são apresentados no Diálogo como "o melhor e mais certo caminho" para a conversão e a perseverança dos indígenas. Na carta denominada Apontamentos de coisas do Brasil, conhecida também como Plano Civilizador de 1558, esse projeto foi melhor explanado por Manuel da Nóbrega. Logo no início da carta, ele deixa isso claro: "Primeiramente o gentio se deve sujeitar e fazê-lo viver como criaturas que são racionais, fazendo-lhe guardar a lei natural", pois "Este gentio é de qualidade que não se quer por bem, senão por temor e sujeição". (NÓBREGA, 2017, p. 245; 246).

A proposta de sujeição forçada, isto é, a transferência dos autóctones das matas para as aldeias resolveria o problema da legalização da escravidão dos indígenas. Pela proposta de Manuel da Nóbrega, só seriam escravizados os índios que não aceitassem a sujeição e a mudança para as aldeias. Esses seriam subjugados por meio de guerra justa. Conclui Nóbrega:

Sujeitando-se o gentio, cessarão muitas maneiras de haver escravos mal havidos e muitos escrúpulos, porque terão os homens escravos legítimos, tomados em guerra justa, e terão serviço e vassalagem dos índios e a terra se povoará e Nosso Senhor ganhará muitas almas e Sua Alteza terá muita renda nesta terra, porque haverá muitas criações e muitos engenhos já que não haja muito ouro e prata. (2017, p. 247).

Assim, a sujeição acaba servindo também à Colônia, que precisava de mão-de-obra escrava para as fazendas. Mas, repetindo: só seriam escravizados os índios que não aceitassem a subjugação. Isso seria feito através do medo e do consentimento voluntário: "Esta aceitação, por sua vez, seria produto do medo servil induzido nos nativos pela ameaça do uso da violência legal em mãos das autoridades seculares". (EISENBERG, 2000, p. 116). Desse modo, para Manuel da Nóbrega, o medo levaria os índios a decidirem livremente pela sujeição. Se não aceitassem, seriam escravizados pelo poder militar e civil, por meio de guerras justas.

Manuel da Nóbrega acreditava que eles optariam por viver nas aldeias, devido ao medo das guerras. A guerra de extermínio contra os Caetés, movida pela Coroa, para vingar a morte do Bispo Sardinha, tinha assustado os indígenas. Uma coisa é guerrear contra machadinhas e flechas, outra contra canhões e armas de fogo. Desse modo, foi pelo medo da violência do poder militar da Colônia que os índios foram catequizados e civilizados. Pelo menos, os que viviam subjugados nas aldeias eram protegidos da escravidão. É pouco, mas é o que foi oferecido aos Tupis pelo Plano Civilizador de Manuel da Nóbrega, em consonância com o Governo Geral de Mem de Sá.

Dessa forma, o sucesso das missões no Brasil ficou atrelado à força coercitiva do Governo Geral. O contrário também é correto. Como se sabe, a expulsão dos franceses do Rio de Janeiro só foi possível devido à participação direta de Manuel da Nóbrega e de José de Anchieta, que conseguiram firmar a paz entre os Tupinambás e os Tamoios. Mas como justificar esse apoio coercitivo para a conversão dos indígenas do ponto de vista teológico? Como fica a liberdade da fé diante disso?

Manuel da Nóbrega usa de toda sua sutileza aqui. A referência principal é Santo Tomás de Aquino, o qual afirma que, em certos casos, a fé pode ser causa do medo. Na verdade, há para Santo Tomás dois tipos de medo, a saber, o medo servil e o medo filial: "a fé é causa do temor, que nos faz temer a punição de Deus e este é o temor servil. A fé é também causa do temor filial pelo qual se teme a separação de Deus ou pela qual se evita, por referência, comparar-se a Ele". (AQUINO, 2004, [II, II, q. 7, a. 1], p. 127). É óbvio que o medo filial é superior. Ele é 
resultado de uma fé já formada, enquanto o medo servil é próprio daquele que ainda não tem uma fé madura. Este pode ser aplicado tanto para os fiéis quanto para os infiéis pagãos. De fato, "aquele que ignora a fé pode aprender a temer a Deus através do medo servil". (EISENBERG, 2000, p. 108). Conclui Eisenberg:

A noção de Nóbrega de que os índios aceitariam a fé através do medo concorda perfeitamente, portanto, com a interpretação tomista do medo, a qual tem a distinção entre medo filial e medo servil em seu centro. Ao discutir o conceito de medo, Nóbrega e seus colegas jesuítas no Brasil estavam de fato empregando a noção tomista de medo servil que, enquanto causa possível da fé, proporcionou uma justificação teológica para a reforma das missões jesuíticas no Brasil. O medo provocado pela ameaça da autoridade secular era análogo ao medo da punição divina. (2000, p. 108).

Entretanto, Nóbrega não podia defender abertamente a conversão pela força ou coerção externa. Isso iria contra os princípios tomistas. Por isso, ele teve de usar de sutileza, ao afirmar que os índios deveriam se converter pela persuasão, "após aceitarem se submeter ao mando dos jesuítas por medo das autoridades coloniais. A sutileza na concepção dessa reforma é que ela possibilita a Nóbrega argumentar que o medo servil somente entra como modo de preparar as almas dos índios para receber a fé cristã, e não como instrumento direto de conversão". (EISENBERG, 2000, p. 108). Com isso, os índios permaneceriam livres para escolher o caminho a tomar: a conversão ou a escravidão. "Nóbrega estava consciente da linha tênue que separa força e persuasão. Através do medo, os índios consentiriam em se submeter à autoridade dos padres, e, em um segundo momento, seriam convertidos pela persuasão". (EISENBERG, 2000, p. 108).

Segundo José Eisenberg, o uso do medo da violência como persuasão teria influenciado o pensamento do jesuíta Juan de Mariana no final do século XVI e, no século XVII, o pacto defendido por Hobbes no Leviatã. A guerra generalizada no Estado de natureza e a ideia de homens naturais violentos teria alguma relação com os "selvagens da América", como assinala o próprio Hobbes:

Pode-se pensar que nunca houve um tempo nem uma condição de guerra como esta; e acredito que nunca foi assim, no mundo inteiro; mas há muitos lugares onde atualmente se vive assim. Porque os povos selvagens de muitos lugares da América, com exceção do governo de pequenas famílias, cuja concórdia depende da concupiscência natural, não possuem qualquer espécie de governo, e vivem em nossos dias daquela maneira embrutecida, como eu disse antes. Seja como for, é fácil conceber qual seria o gênero de vida quando não havia poder comum a recear, através do gênero de vida em que os homens que anteriormente viveram sob um governo pacífico costumam deixar-se cair, numa guerra civil. (HOBBES, 1968, p. 187).

Todavia, apesar dessa sintonia, uma diferença radical se impõe entre o estado natural hobbesiano e os índios brasileiros, em particular, tal como foram considerados por Manuel da Nóbrega. Para Hobbes, o homem natural é atomista, sem nenhuma relação comunitária, contrastando claramente com o homem social aristotélico, enquanto para Nóbrega, como vimos, os indígenas, apesar de violentos e incivilizados, são "próximos", com uma vida social elementar. Nesse aspecto, mais perto da posição de Nóbrega, temos a teoria política de Juan de Mariana. Encontramos no início do primeiro capítulo do De Rege et regis institutione, de 1598, intitulado justamente "o homem é por sua natureza animal sociável", a seguinte constatação:

Em um princípio, os homens, como as feras, andavam errantes pelo mundo, nem tinham lugar fixo, e não pensavam em nada a não ser conservar a vida e obedecer ao agradável instinto de procriar e educar a prole. Não havia leis que os obrigassem nem chefes que 
mandassem neles; somente por um certo impulso da natureza cada família tributava o maior respeito àquele que por sua idade parecia ter sobre todos uma decidida preferência. É verdade que, à medida que os homens aumentavam em número, eles apresentavam, embora de maneira vaga e grosseira, as formas de sociedade, ou melhor, de um povo. Faltava o chefe de família: o avô, o pai, os filhos e os netos estavam distribuídos em vários grupos, formando uma única aldeia. (MARIANA, 2018, p. 29).

Mas essa sociabilidade natural não implica a ausência da violência. Antecipando a discussão sobre a condição humana violenta em Hobbes, ${ }^{14}$ Mariana afirma que "as desigualdades naturais entre fortes e fracos acabaram por produzir um estado de guerra de 'todos contra todos'"'. (EISENBERG, 2000, p. 119). Mais precisamente:

A vida do homem não estava segura, nem contra as muitas feras que povoavam a Terra quando não era cultivada e não se tinha destruído nenhuma floresta, nem contra seus semelhantes, entre os quais, confiando cada um em suas próprias forças, aqueles que podiam se arrojavam contra a vida e as fortunas dos mais fracos, sem oposição, como seres ferozes e selvagens, aterrorizando e amedrontando, de acordo com quão fortes se sentiam. (...). Aonde, então, a inocência e a pobreza poderiam encontrar abrigo contra tantos latrocínios, saques e matanças? (MARIANA, 2018, p. 33).

Desse modo, "a interpretação do conceito de estado de natureza que ganhou notoriedade através dos escritos de Hobbes já estava de fato presente em Mariana". (EISENBERG, 2000, p. 120). Mas o que nos interessa sobretudo é observar a simetria que há no texto de Mariana com a narrativa da experiência missionária de seus irmãos jesuítas, em particular, com o relato do padre Manuel da Nóbrega. Como demonstra José Eisenberg em sua tese, os jesuítas possuíam um sistema de comunicação por meio de cartas, que eram copiadas e lidas em todas as comunidades, espalhadas pelo mundo inteiro. É muito provável que Juan de Mariana tenha tido acesso a essas cartas e, posteriormente, incorporado as teses de Manuel da Nóbrega em seu De Rege. (Cf. MARGUTTI, 2013, p. 243). De fato:

A descrição do 'estado de natureza' apresentada por Mariana poderia ter sido retirada de qualquer carta edificante escrita por Nóbrega no Brasil. Sua caracterização dos homens naquele estado se assemelha em muitos aspectos à etnografia produzida pelos jesuítas sobre os índios Tupi; (a) eles se parecem com as bestas (similitudine), mas são humanos; (b) eles só conhecem os instintos (Mariana fala da procriação e do cuidado com a prole enquanto os jesuítas do Brasil falam de procriação e guerra); (c) eles não têm lei nem rei (os missionários adicionam a falta de fé); (d) e a única autoridade reconhecida por eles é a da idade (os missionários também falam da autoridade do orador e do chefe guerreiro (EISENBERG, 2000, p. 122).

\section{Considerações finais}

Dissemos no início do texto que a violência é inerente à história brasileira. Ela se manifestou claramente desde o princípio da colonização, por meio dos encontros dos lusitanos com os povos nativos do Brasil. Ademais, pode-se dizer ainda que a violência vigorava nas

\footnotetext{
${ }^{14}$ É importante frisar que, para Hobbes, há uma igualdade radical entre os indivíduos no estado de natureza. Essa igualdade não se dá apenas no aspecto físico, mas também no tocante às forças espirituais, de modo que a diferença entre os seres humanos é irrisória. "A natureza fez os homens tão iguais nas faculdades do corpo e do espírito que, embora por vezes se encontre um homem manifestamente mais forte de corpo, ou de espírito mais vivo do que outro, mesmo assim, quando se considera tudo isso em conjunto, a diferença entre um e outro homem não é tão considerável para que qualquer um possa com base nela reclamar qualquer benefício a que outro não possa também aspirar, assim como ele". (HOBBES, 1968, p. 183). A discórdia se instaura depois, por meio da competição, da desconfiança e da busca da glória. (HOBBES, 1968, p. 185).
} 
guerras endógenas entre as tribos indígenas e na prática do canibalismo, por exemplo. Diante da violência da prática antropofágica dos índios brasileiros, duas posições se destacaram no século XVl: a de Michel Montaigne e a dos missionários jesuítas. O texto de Montaigne se baseia no relato de seu cozinheiro, que estivera no Brasil e lhe forneceu informações a respeito da vida dos índios brasileiros. Montaigne não nega o barbarismo da antropofagia. O que o aborrece "não é o fato de sermos capazes de julgar adequadamente as falhas deles, mas de revelar-nos cegos para as nossas próprias". (MARGUTTI, 2013, p. 241). Como assinala Margutti, mesmo sem idealizar francamente os indígenas brasileiros, é provável que o seu relato tenha influenciado "a leitura idealizante de Rousseau". Por isso, a posição de Montaigne pode ser considerada "como uma refutação sardônica da abordagem enviezadamente 'realista' dos jesuítas". (MARGUTTI, 2013, p. 242).

Seja pela leitura "idealista" de Montaigne ou pela "realista" de Nóbrega, o modo de vida dos indígenas brasileiros tiveram uma influência determinante na filosofia política moderna. No caso de Nóbrega, como vimos, seguindo as pesquisas de José Eisenberg, o uso do medo como tática persuasiva acabou influenciando o pensamento de Juan de Mariana e, por meio deste, o contratualismo de Hobbes ${ }^{15}$. É certo que o medo em Hobbes sofre uma transformação radical. Ele não é mais causa da persuasão e da fé, mas um instinto puramente físico, sem nenhuma relação com a fé divina. Todavia, não se pode negar que um tipo de fé (fides) subsiste no pacto (foedus). Fides e foedus têm a mesma origem etimológica. O pacto (foedus) pressupõe uma fé ou uma fidelidade (fides) entre os contratantes e vice-e-versa.

Além da influência sobre o contratualismo hobbesiano, a discussão sobre a liberdade e a escravidão dos índios movida pelos jesuítas no Brasil ecoará no pensamento jusnaturalista de Luís de Molina e, por meio deste, na concepção de Hugo Grotius, "que altera o conceito de direito natural, concebido como dádiva divina inalienável, substituindo-o pelo conceito de direito subjetivo, entendido como uma faculdade humana que a pessoa pode alienar voluntariamente". (MARGUTTI, 2013, p. 242). A questão da escravidão voluntária dos indígenas brasileiros tem uma longa história, que se inicia com o debate entre os jesuítas Quirício Caxa e Manuel da Nóbrega no final da década de 1560 e terminará apenas no século XVII com as teses contra a escravidão indígena do padre Antônio Vieira. Caxa defendia contra Nóbrega o direito do índio maior de vinte e um anos optar livremente pela escravidão. Segundo Eisenberg, a referência principal de Caxa para a defesa do direito subjetivo dos índios brasileiros é o pensamento de João Gerson. (EISENBERBG, 2000, p. 149). Com efeito, na opinião de Michel Villey, o pensamento subjetivo moderno tem suas raízes no nominalismo do século XIV.É o pensamento nominalista de Ockham e de João Gerson que abre as portas para o pensamento moderno. (VILLEY, 2009, p. 250-298). Não é nosso objetivo se alongar agora nessa importante questão. Basta ressaltar novamente que "os debates sobre a escravidão dos índios nas colônias e a opinião de Caxa, em particular, tiveram um papel importante na opção de Molina pelo conceito de direito subjetivo" exposto no livro De lustitia et lure (EISENBERG, 2000, p. 162) e, por meio deste, na obra De Jure Bell ac Pacis de Hugo Grotius. ${ }^{16}$

\footnotetext{
${ }^{15}$ Segundo o professor João Quartim de Moraes, Juan de Mariana pode ser considerado "como um dos precursores das teorias do contrato" (1993, p. 9). Ademais, acrescenta Quartim, não obstante as diferenças, o conceito de "soberania popular" do De Rege de Mariana teria prefigurado ainda a ideia de vontade popular de Rousseau: "o apego do autor do De Rege às prerrogativas da soberania popular sugere tanto uma nostalgia das velhas liberdades da comuna medieval quanto uma profética antevisão do contrato social, que encontraria em Rousseau, dois séculos mais tarde, sua expressão filosófica radical". (QUARTIM DE MORAES, 1993, p. 10).

${ }^{16}$ Diferentemente do Direito Romano clássico, que define o jus como "a vontade constante e perpétua de dar a cada um o seu direito" (Iustitia est constans et perpetua voluntas ius suum cuique tribuendi) (DIGESTO, 1.1.10.1), o direito subjetivo moderno "não é mais um ter, mas uma qualidade inerente ao indivíduo". (VILLEY, 2008, p. 142). O que é determinante para o indivíduo agora não
} 
Conforme descrito acima, acreditamos que o conceito de medo como tática persuasiva e a discussão em torno da escravidão voluntária constituem elementos suficientes para evidenciar a importância do pensamento brasileiro quinhentista na filosofia política moderna. E isso é de fato surpreendente, principalmente para quem imaginava o pensamento colonial sempre alheio ao pensamento moderno. Infelizmente, por questões óbvias de espaço, optamos neste trabalho priorizar apenas o uso do medo pelos missionários jesuítas. Por meio deste os indígenas seriam convencidos a abandonarem as florestas para viverem nas aldeias protegidas pelos jesuítas e pelo poder colonial. Esperamos em uma próxima oportunidade tratar com mais propriedade do tema da escravidão voluntária dos índios brasileiros e de seu provável impacto na teoria do direito subjetivo em Molina e Grotius. ${ }^{17}$ Independentemente disso, julgamos que ficou claramente demonstrado, a partir das reflexões do padre Manuel da Nóbrega, quão basilar é o conceito de violência para o Ensino da Filosofia no Brasil.

\section{Referências}

AQUINO, T. Suma Teológica. II secção da II parte - Questões 1-56. São Paulo: Loyola, 2004.

ARANTES, P. Um departamento Francês de Ultramar. Estudos sobre a formação da cultura filosófica uspiana (Uma experiência nos anos 60). São Paulo: Paz e Terra, 1994.

BARRETO, T. Estudos de Filosofia. São Paulo: Grijalbo, 1977.

BARROS, R. S. M. A significação Educativa do Romantismo Brasileiro: Gonçalves de Magalhães. São Paulo: Grijalbo, 1973.

BRANCO, J. C. Eric Weil. Limites de la démocratie. In: Revista Argumentos, n. 21, 2019, p. 249-259.

CARVALHO, L. R. A formação Filosófica de Farias Brito. São Paulo: Saraiva, 1977.

CRUZ COSTA, J. Contribuição à História das Ideais no Brasil. Rio de Janeiro: Civilização Brasileira, 1967.

EISENBERG, J. As Missões Jesuíticas e o Pensamento Político Moderno. Encontros Culturais, Aventuras teóricas. Belo Horizonte: UFMG, 2000.

GROTIUS, H. O Direito da Guerra e da Paz (De Jure Bell ac Pacis). Ijuí: Unijuí, 2004.

HOBBES, T. Leviathan. Londres: Penguin, 1968.

JUSTINIANO. DIGESTO. Livro I. Edição bilíngue: Latim/Português. São Paulo: Editora Revista dos Tribunais, 2000.

MARGUTTI, P. História da Filosofia do Brasil. O período Colonial (1500-1822). São Paulo: Loyola, 2013. MARIANA, J. Del Rey y de la Institución Real. Barcelona: Deusto, 2018.

MONTAIGNE, M. Ensaios. São Paulo: Editora 34, 2016.

MONTEIRO, J. M. Negros da Terra. São Paulo: Companhia das Letras, 1994.

é mais a posse do objeto em si, mas a liberdade para possuir. Nas palavras de Grotius: "Tomado neste sentido o direito é uma qualidade moral ligada ao indivíduo para possuir ou fazer de modo justo alguma coisa". (2004, p. 74). Mais claramente, segundo o comentário de Villey, "o direito seria, pois, uma qualidade da pessoa, que a torna apta para possuir ou realizar uma certa ação, sem que a moral seja ofendida" (VILLEY, 2009, p. 666). Para o intérprete francês, o direito subjetivo seria, enfim, a própria "culminação do sistema" grociano (VILLEY, 2009, p. 670). Esta posição de Villey não é pacífica para todos os intérpretes de Grotius. Luiz Felipe Sahd, por exemplo, defende que o direito entendido como qualitas moralis do indivíduo é de fato a grande novidade de Grotius, porém, discorda que esta definição deva ser utilizada "para a compreensão do livro como um todo". (SAHD, 2016, nota 31, p. 138).

17 Sobre isso, ver José Eisenberg (2000, p. 125-166). 
NÓBREGA, M. Obra Completa. São Paulo: Loyola, 2017.

QUARTIM DE MORAES, J. A justificação do tiranicídio no pensamento proto-liberal de Juan de Mariana. Campinas: Unicamp, 1993. [Primeira versão].

PRADO JUNIOR, B. Alguns Ensaios. Filosofia, Literatura e Psicanálise. São Paulo: Max Limonad, 1985.

SAHD, L. F. N. A. Grotius: A Política Proveniente do Direito Natural. In: Anor Sganzerla, Antonio José Romera Valverde, Ericson Falabretti (organizadores). O Pensamento político em movimento: ensaios de filosofia política / Curitiba: PUCPRess, 2016.

VILLEY, M. Filosofia do Direito. Definições e fins do Direito. Os meios do Direito. São Paulo: Martins Fontes, 2008.

VILLEY, M. A formação do pensamento jurídico moderno. São Paulo: Martins Fontes, 2009.

WEIL, E. Lógica da Filosofia. São Paulo: É Realizações, 2012.

WEIL, E. A Educação Enquanto Problema de Nosso Tempo. In: Hannah Arendt, Eric Weil, Bertrand Russel, Ortega y Gasset. Quatro Textos Excêntricos. Lisboa: Relógio d'Água, 2000, p. 55-70.

Sobre o autor

\section{Evanildo Costeski}

Graduado em Filosofia pela Universidade do Sagrado Coração, mestrado em Filosofia pela Pontifícia Universidade Gregoriana (1997) e doutorado em Filosofia pela Pontifícia Universidade Gregoriana (2004). Pós-doutorado no Centro de História e Cultura da Universidade Nova de Lisboa (2012). Professor Associado III da Universidade Federal do Ceará. Membro correspondente externo do Instituto Eric Weil (IEW) da Université Charles-de-Gaulle Lille 3. Professor do Curso de Mestrado e Doutorado em Filosofia da UFC e do Mestrado Profissional em Filosofia (PROFFILO). Coordenador Adjunto de Programas Profissionais da área de Filosofia (2018-2021). Tem experiência na área de Filosofia, atuando principalmente nos seguintes temas: Ensino de Filosofia, Filosofia Brasileira, Kierkegaard, Eric Weil, Violência, Religião e Relações Internacionais. 